\title{
The development and cultivation of tomatillo (Physalis ixocarpa Brot.) under the climatic conditions of Poland. I. Local cultivars, growth of aboveground vegetative parts, probable resistance to Phytophthora infestans
}

\section{LESZEK S. JANKIEWICZ*, ELŻBIETA HORODECKA** and JAN BORKOWSKI*}

*Research Institute of Vegetable Crops, ul. Konstytucji 3 Maja 1/3, 96-100 Skierniewice Poland ** Laboratory of Genetics and Breeding, Reguly, Opacz 05-815, Poland

(Received: March 30, 1988)

\section{Abstract}

Tomatillo (Physalis ixocarpa Brot.) grows in Poland much like in Mexico although its development cycle is much longer and lasts 6 months. It was sown at the beginning of April in a heated greenhouse, and transferred later on to a heated plastic tunnel. It was transplanted to a field about May 20 when danger of frosts had passed. Three local cultivars of Mexican origin were used and are briefly described. Their vegetative growth characteristics in Poland were similar to that of cv. Rendidora, which was described earlier in Mexico. The tomatillo internodes and leaves became progressively smaller with age. Tomatillo leaves and fruits were not attacked by Phytophthora infestans in the field and laboratory. Inoculation with tomato strains of this disease was without effect.

Tomatillo (husk tomato) Physalis ixocarpa Brot. is a plant of Mexican origin (Rojas-Rabiela, 1983), cultivated widely in central Mexico (S a rayMeza and Loy a, 1978). It was also introduced to the USSR during Vavilov's expeditions (Medvedev, 1958), and is now cultivated there in home gardens. It was introduced to Poland in 1982 by the senior author. The growth and fructification of tomatillo in Mexico has been described in several publications (Saray-Meza, 1977; Saray-Meza et al., 1978; Cartujano-Escobar et al., 1985 a, b; 1987; Mulato-Brito et al., 1985). This work was designed to show the behaviour of tomatillo and to describe its growth in the climatic conditions of Poland. The first introductory trials of tomatillo cultivation in Poland were done by Borkowski (1984).

As described earlier, in Mexico (Mulato-Brito et al., 1985; Cartujano-Escobar et al., 1985a), the tomatillo plant forms a true axis with 3-5 internodes, ending with the flower bud, leaf and two ramifications containing one internode. Each of these ramifications ends with the same set of 
appendices: a flower bud, leaf and two ramifications of one internode. This "unit" repeats up to the end of plant life. More rarely, the set: "one flower bud, two leaves and one ramification" is found. In the first three nodes, the two ramifications grow equally, forming 4 main apparent branches. Later on, in each node one ramification grows more than the other. In this manner, a system of main and lateral apparent branches of 1st, 2nd, 3rd order is formed (compare Fig. 2.).

The aim of this paper was:

1. To ascertain if the preliminary observations of Borkowski (1984), on the dates and conditions of sowing, pricking off, transplanting and method of cultivation of tomatillo in Polish conditions are acceptable for all three local cultivars used;

2. To check if the growth characteristics of three different tomatillo cultivars in Polish conditions resemble those of cv. Rendidora grown in Mexico;

3. To make observations on the incidence of Phytophthora infestans on tomatillo in Polish conditions and to test the resistance of tomatillo to this disease.

\section{MATERIALS AND METHODS}

The observations were conducted in the experimental field of the Research Institute of Vegetable Crops in Skierniewice and in the garden of this Institute in the same locality, in the years 1986 and 1987. The climatic conditions in these years differed markedly (Fig. 1A, B). In 1986 the 2nd and 3rd decades of May were exceptionally warm, with average temperatures of 15.5 and $15.6^{\circ} \mathrm{C}$, respectively: whereas, in 1987 , they were 10.8 and $11.4^{\circ} \mathrm{C}$, respectively. This caused great delay in tomatillo development in 1987. On the other hand, there were two drought periods in 1986, at the end of June and during the end of July and beginning of August when the plants suffered from a shortage of water. In 1987 the plants did not suffer from drought.

The soil type was pseudo-podsolic formed from sandy loam. Its organic matter content amounted to about $1-1.2 \%$ and $\mathrm{pH} / \mathrm{H}_{2} \mathrm{O}$ about 6 .

Tomatillo plants are mainly of the prostrated type, so they were grown tied to sticks in 1986 and tied to plastic strings extended between sticks in 1987. The distance between rows was $1 \mathrm{~m}$, and $50 \mathrm{~cm}$ between plants.

The plants of three local cultivars were taken for observation:

1. 'Rendidora B1' plants originated from the seeds of cv. Rendidora, which is widely cultivated in Mexico. The seeds of this cultivar are also sold in the USA (see American Vegetable Grower, December 1986 p. 31). The seeds were received due to the courtesy of the Universidad Autonoma Chapingo.

2. 'Antocyjanowa' is of a rather "wild" type. It originated from fruit bought in the market at Mazatlan (Sinoloa), Mexico. 

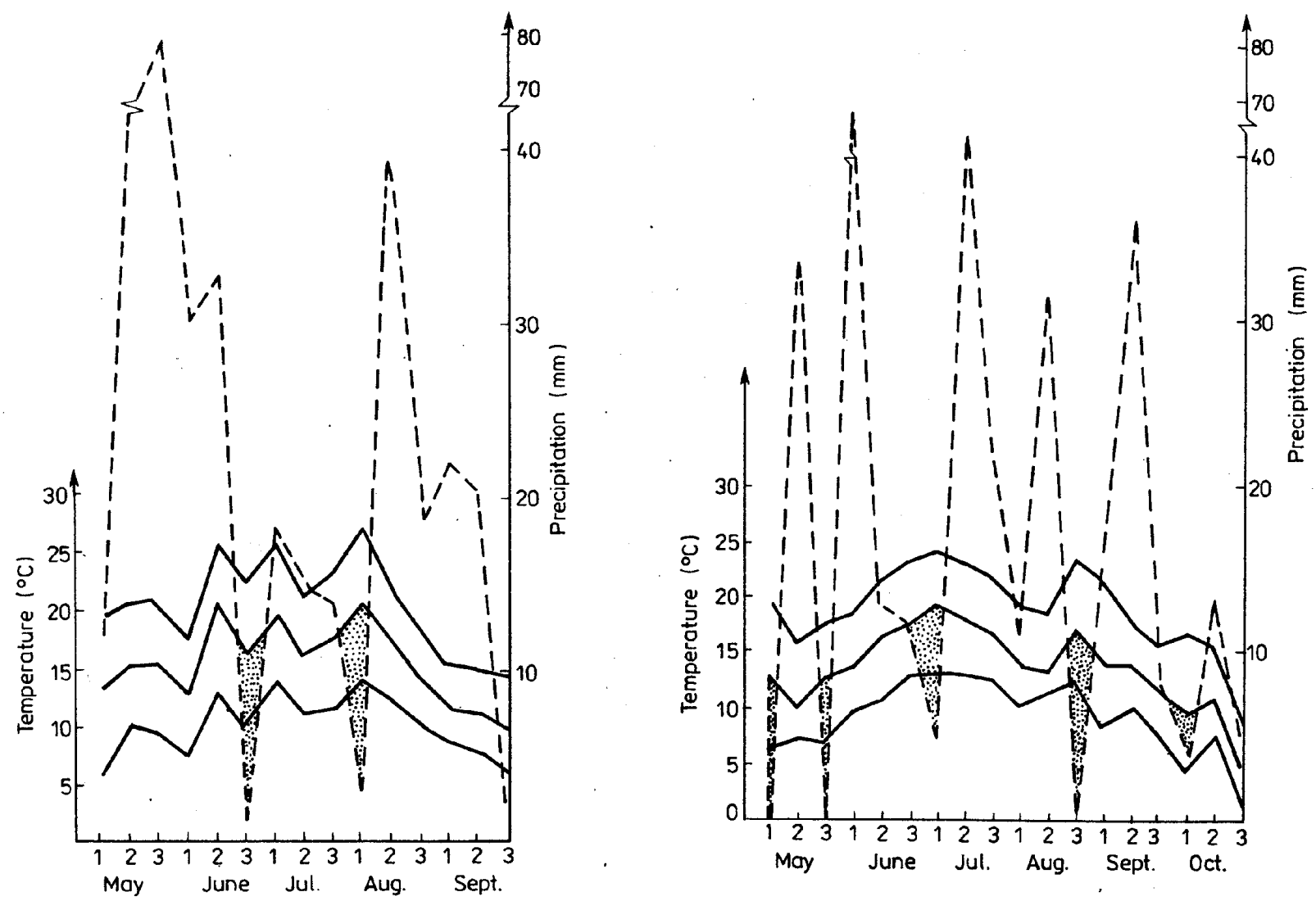

Fig. 1. Meteorological data for Skierniewice: A - 1986, B - 1987. Solid lines - decade averages of maximal, average and minimal temperatures; broken lines - decade sums of precipitations. Dotted regions - dry weather. Method of presentation according to Walter and Leith (1960) 
3. 'Bujna' originated from fruit bought in the market in Texcoco (Mexico). In 1987 five populations were selected within cv. Bujna, which we named Bujna 1, Bujna 2 etc.

The plants were grown in two sites:

- the first resembled a home garden, protected from wind by trees and buildings. The plants grown in this site were watered 3 times during the dry periods in 1986 with about $3 \mathrm{dcm}^{3}$ of water per plant each time. In 1987 there was no need for watering. On this site, only cv. Rendidora B1 was cultivated.

- the second site was an open field. There was no protection from wind and no irrigation during the drought in 1986. On this site, all three cultivars, Rendidora, Antocyjanowa and Bujna, were planted.

Methods of cultivation were adapted to the climatic conditions of Poland. The seeds were sown from April 1 to 10 (depending on the year), in cases with peat substrate in heated greenhouse with the temperature oscilating from 18 to $25^{\circ} \mathrm{C}$ during the day, and 12 to $16^{\circ} \mathrm{C}$ during the night. Tomatillo plantlets grow faster and need a lower temperature then those of tomato: therefore in Polish conditions, the sowing date should be no earlier than April 5th if the date of transplantation to the open ground is foreseen as May 20.

Two weeks after emergence, the plants of 'Rendidora B1' destined to be planted in "garden conditions", were transferred to pots with peat substrate and left in the greenhouse, up to May 9 in 1986 or to May 15 in 1987, when they were transplanted to the garden.

The plants destined to be planted in the open field were pricked out when their cotyledons were well formed, then transferred to the heated plastic tunnel where they were grown in cases. They were transplanted to the open field on May 23 in 1986 and on May 20 in 1987.

The plants were measured every two weeks. In some cases, as indicated in the text, the plants or their parts were measured more frequently. The presented results are based on averages of 16 plants during the first 3 measurements. Thereafter, the number of plants was reduced to 8 and only one main apparent axis out of four was measured because they all behaved similarly in a given plant. The diameter of the stem was measured $10 \mathrm{~cm}$ above the soil level.

Resistance to late blight (Phytophthora infestans (Mont.) de Bary) was investigated in 'Bujna-3' and 'Bujna-1' plants growing in the experimental field of the Laboratory of Genetics and Breeding of the Research Institute of Vegetable Crops in Reguły near Warsaw. The seedlings were cultivated in Skierniewice as described above. One day before transplanting the field was sprayed with the herbicides Sencor $\left(0.3 \mathrm{~kg} \cdot \mathrm{ha}^{-1}\right)$ and Devrinol $50 \mathrm{WP}(2.5$ $\left.\mathrm{kg} \cdot \mathrm{ha}^{-1}\right)$. The plant protection was done with Ripcord $(0.04 \%$ on May 31$)$, Pirimor $(0.05 \%$ on July 7$)$ and Lannate $(0.15 \%$ on July 14$)$. No protection against late blight was done.

The observations of natural infection with late blight were done during the 
whole vegetation season. The laboratory tests for the resistance to late blight were done with leaves in early August and with fruits in early September. The method of Horodecka (1989) was followed.

Inoculum was prepared from 1-week culture of fungus. The isolates were applied on the tomato leaves in an incubation cabin with the temperature $15-18^{\circ} \mathrm{C}$. The suspension of zoospores in distilled and sterilized water was standarized to $50 \times 10^{3} \mathrm{dm}^{-3}$. Pathogenicity of the mixture of isolates was checked on the model tomato cultivars and breeding lines (Table 1). The late blight strains used had high pathogenicity.

Table 1

Infection of leaves and fruits by Phytophthora infestans in laboratory conditions. Summer 1988

\begin{tabular}{|c|c|c|c|c|}
\hline \multirow[b]{2}{*}{$\begin{array}{c}\text { Cultivar or } \\
\text { line }\end{array}$} & \multirow[b]{2}{*}{$\begin{array}{l}\text { Leaf infection } \\
\text { in 6-degree scale }\end{array}$} & \multicolumn{3}{|c|}{ Fruit infection symptoms as $P(\%)^{*}$} \\
\hline & & spot & $\begin{array}{c}\text { fur of } \\
\text { mycelium }\end{array}$ & $\begin{array}{l}\text { the flesh } \\
\text { streaked with } \\
\text { mycelium }\end{array}$ \\
\hline \multicolumn{5}{|l|}{ Tomatillo } \\
\hline 'Bujna 3-7' & 0 & 0 & 0 & 0 \\
\hline 'Bujna 3-14' & 0 & 0 & 0 & 0 \\
\hline 'Bujna 1-15' & 0 & 0 & 0 & 0 \\
\hline \multicolumn{5}{|c|}{ Resistance models wild type } \\
\hline 'West Virginia 700' & 0.15 & 0.20 & 0 & 0 \\
\hline 'Ottawa $30^{\prime}$ & 0.60 & 1.50 & 0 & 0 \\
\hline 'Geneva T-5' & 0.88 & 0.00 & 0 & 0 \\
\hline 'PI 224675' & 0.51 & 0.00 & 0 & 0 \\
\hline \multicolumn{5}{|l|}{ Tomato cultivars } \\
\hline $\begin{array}{l}\text { 'New Yorker' } \\
\text { (partly resistant) }\end{array}$ & 0.98 & 13.50 & 4.60 & 3.30 \\
\hline $\begin{array}{l}\text { 'Riposta' } \\
\text { (susceptible) }\end{array}$ & 5.00 & 43.10 & 19.20 & 13.60 \\
\hline
\end{tabular}

$* P=\frac{\text { diameter of spot }}{\text { transverse diameter of fruit }} \times 100(\%)$.

The leaves to be tested were taken from the middle part of a stem of each plant. They were placed in the transparent plastic boxes with wet filter paper inside and inoculated with the fungus by spraying the lower (abaxial) side. The next day the leaves were reversed. The degree of infection was visually assessed six days later according to the 6 degree scale, where 0 means no symptoms and 5 means necrosis of more than $3 / 4$ of leaf blade. The fruits for tests were picked up when unripe, one fruit from a plant. They were removed from calice cover and placed in transparent plastic boxes on a wet filter paper. They were inoculated by spraying with the mentioned suspension of zoospores. The 
degree of infection $(P)$ was visually assessed 14 days later according to a formula:

$$
P(\%)=\frac{\text { diameter of the infected region }}{\text { transverse diameter of the fruit }} \times 100
$$

The three symptoms were taken parallelly into account: spot, fur, and fruit flesh streaked with mycelium.

The tomatillo leaves or fruits and those of the model tomato cultivars and breeding lines were tested at the same time.

\section{RESULTS}

The characteristics of the three local cultivars.

Observations of the cultivar Rendidora B1 showed very uniform fruit characteristics: a yellow or a yellow-green colour, a mild taste acid-sweet and somewhat astringent, and the diameter $4-6 \mathrm{~cm}$. The fruit fell when overripe. The plants were of medium size and were mostly of a prostrated or semiprostrated type. They were not resistant to drought in 1986 in field conditions. They lost a great number of their leaves during drought and their growth and fructification were inhibited for several weeks. In the garden, where three waterings were applied during the driest periods, the plants grew abundantly, and preserved their leaves. 'Rendidora B1' is a medium early cultivar.

The plants of cultivar Bujna were much less uniform. The particular individuals had fruit of different ground colour - dark green, green to yellow-green, yellow, gold-yellow, and frequently the fruit had violet blush. The size of the fruit was mostly large, $4-6 \mathrm{~cm}$ in diameter. The flavour was rather tasty, acid-sweet, however, always with an astringent aftertaste, characteristic of almost all forms. The fruit of some individuals were insipid. The calice in ripe fruit was frequently very open, not reaching even half of the fruit. The fruit usually fell when ripe. The size of the plant was mostly large and erect forms were very frequent. The plants were resistant to drought in 1986. 'Bujna' is a medium late cultivar.

The cultivar Antocyjanowa had mainly small size fruit. Individuals with medium to large-sized fruits were infrequent. Their colour was mainly dark-green, pale-green or green-yellow. Very frequently the fruits had violet blush on all parts uncovered by the calice envelope, however, fruits of some plants had all surface dark violet and even the flesh of red-violet colour. The taste was acid, often somewhat bitter usually not pleasant. The growth of the plants was medium. The prostrated forms were more frequent than the erect ones. The plants suffered little from drought in 1986. 'Antocyjanowa' is a late cultivar.

The dynamics of growth and vigour of the plants was assessed by measuring the stem diameter (Fig. 4). The plants of 'Rendidora B1' grown in 

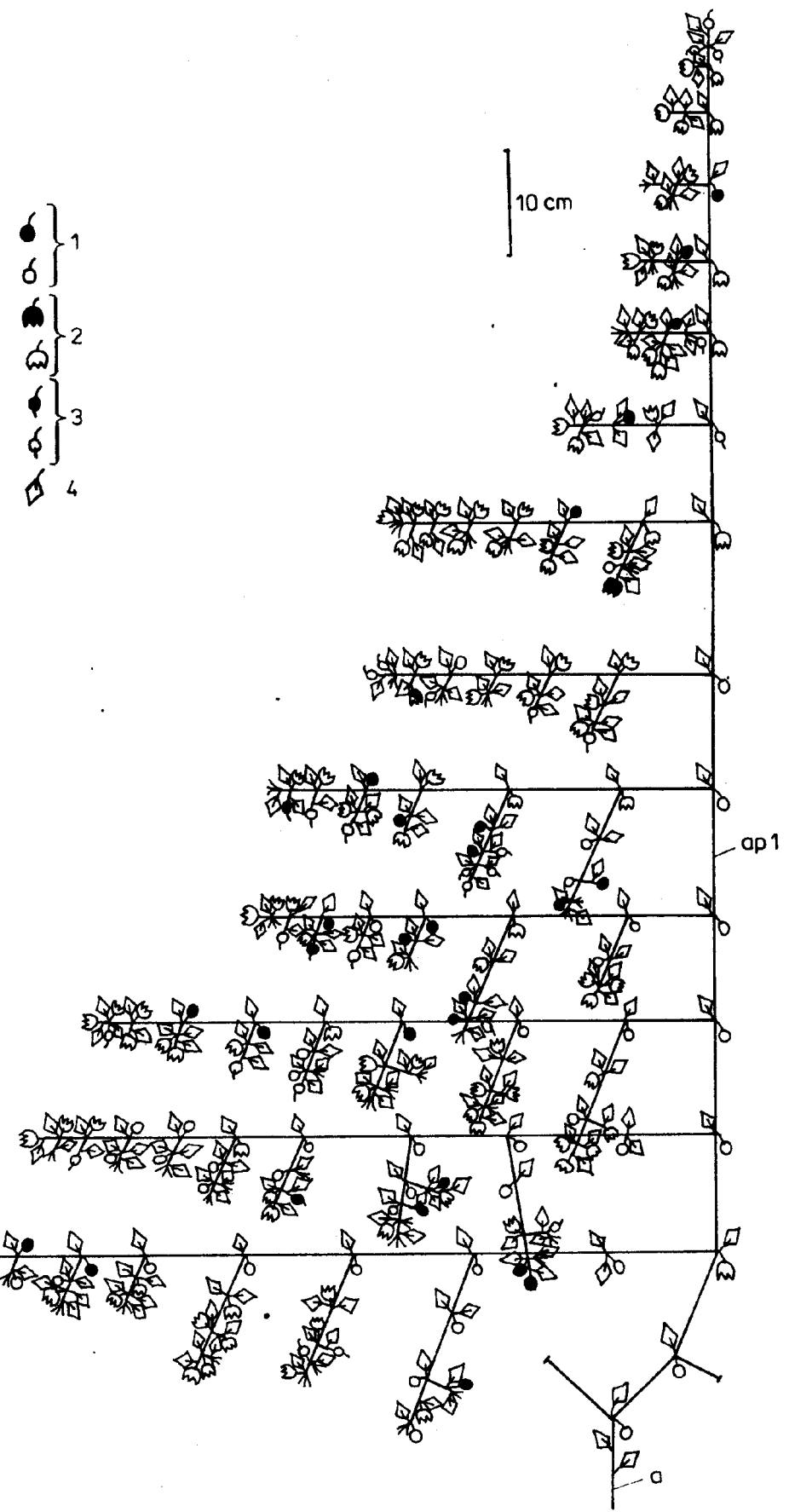

Fig. 2. Scheme of 'Rendidora B1' plant cultivated in the garden, measured on August 22, 1986, 1 - fruit, 2 - flower, 3 - bud (black colour - existing organ; white - abscised one), 4 - a leaf existing or abscised. The shoots growing on the true main axis " $a$ " are shown on Figure 3. Only one main apparent axis (ap 1) is shown in detail 
the garden showed great difference in their diameter between the years 1986 and 1987. This indicates that the conditions of growth in the early part of the season are of great importance for the further development of this early cultivar of tomatillo. On the other hand, the cv. Rendidora B1 was growing much less in the field than in the garden in 1986. As mentioned, the plants in the garden were planted on May 9 in this year, and those in the field, on May 23. In

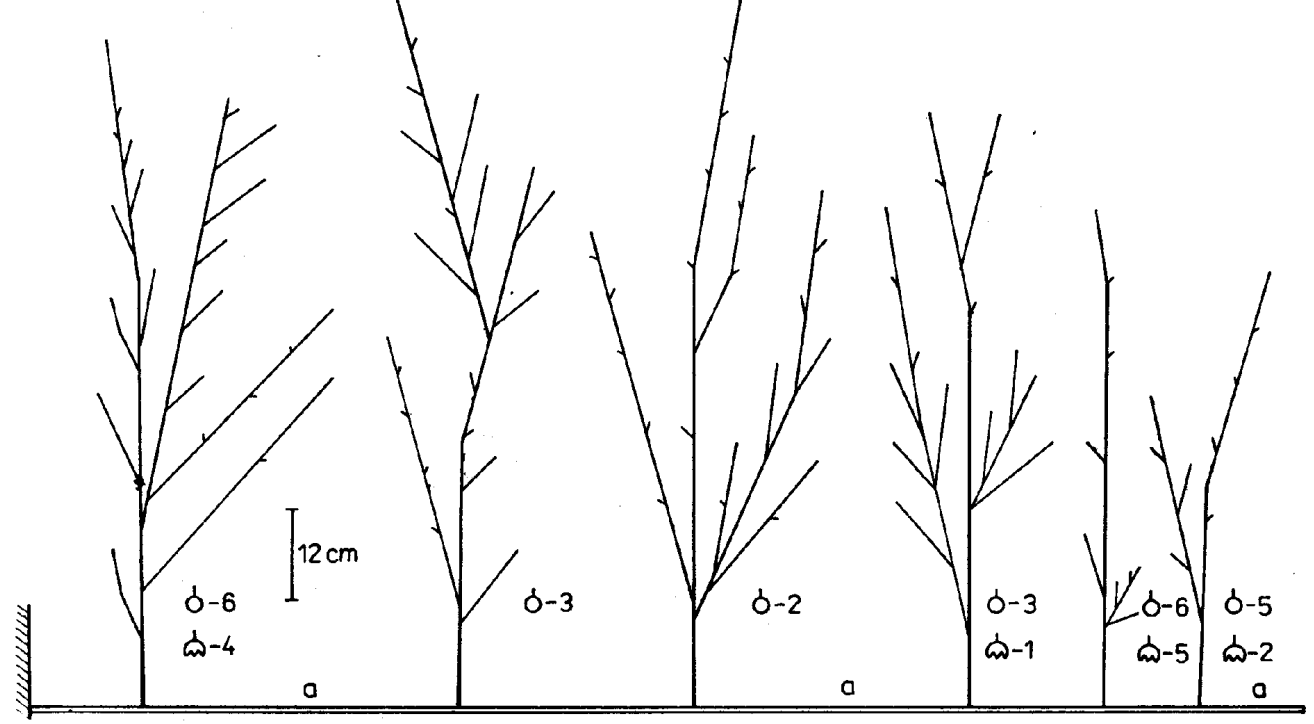

Fig 3. Lateral shoots growing on the true main axis of tomatillo. At their base are marked the flowers and fruits found on the shoot on August 22. Only the lateral branches are at the scale. a - the true main axis.

addition, plants in the field suffered from drought and those in the garden were irrigated during the dry period. All these observations indicate that the plants of 'Rendidora B1' are suitable for home garden cultivation. but are not well adapted for fieldgrowing.

In 1987, the plants of medium late cultivar Bujna 2 were growing much more intensively in the field than the plants of 'Rendidora B1' in the garden. This confirms the statement that cultivar Bujna is of medium late type and is rather well adapted to cultivation in field conditions (Fig. 4).

The coefficient of variability for stem diameter was $8-38 \%$ depending on the cultivar and date.

The early formed internodes in the main apparent axis showed similar length but later on, their dimensions decreased gradually as the vegetative season progressed (Figs. 2 and 5). The coefficient of variability for the earlier formed internodes was low: $10-20 \%$ and for the late ones was high $57-74 \%$. 


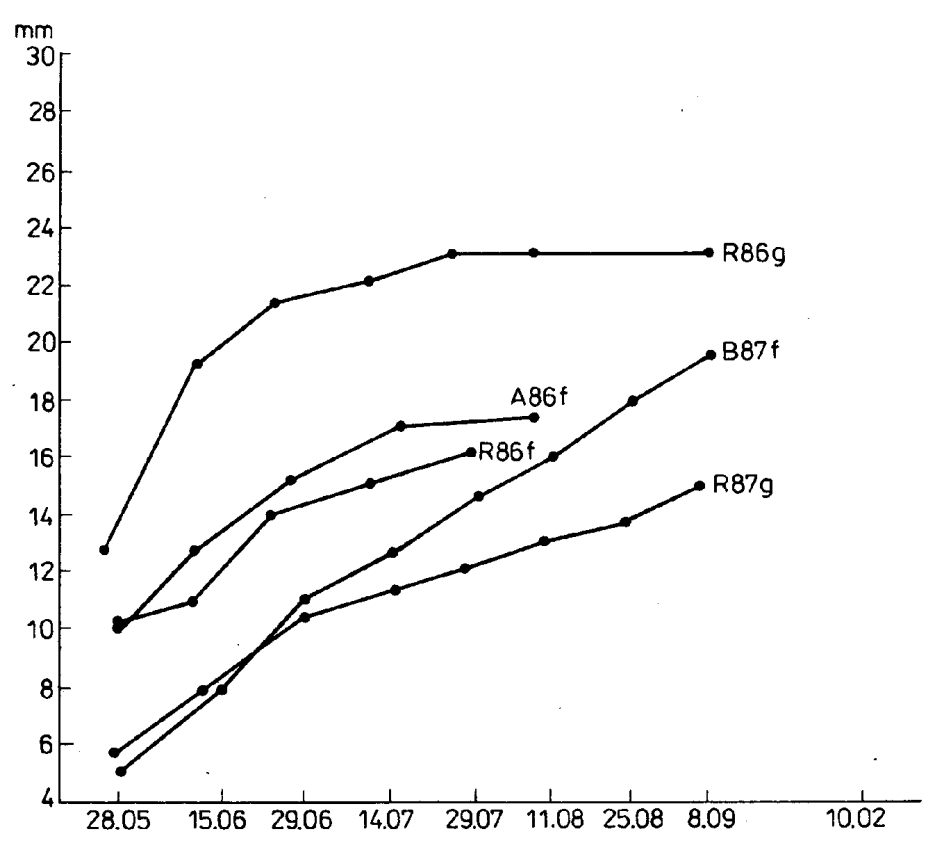

Fig. 4. Thickenning of the stem. R - cv. Rendidora B1, A - cv. Antocyjanowa, B - cv. Bujna 2: g - garden conditions, f - open field: 86 and 87, the experiments of 1986 and 1987

Similarly, in the apparent lateral axes (Fig. 6) initial, consecutive internodes did not differ much with their length. Frequently, the second internode was the longest. Further on, however, there was a steep decrease in internode length. Thus gradual shortening of internodes of main and lateral axes toward the end of plant life may be considered an important element of tomatillo plant shape and was observed in all cultivars (Fig. 2). It may be also considered a symptom of ageing.

Unequal growth of the one-internode branches situated at each node of the main apparent axis was observed in cv. Rendidora by Mulato-Brito et al. (1985). The same phenomenon was found in the three cultivars investigated in our work. Figure 7 shows the ratio of the length of these two branches situated on consecutive nodes along the apparent main axis. In each node the longer branch " $a$ " forms the prolongation of the main apparent axis, whereas the shorter one " $b$ " initiates the apparent lateral axis (compare Mulato-Brito et al., 1985). The coefficient of variability for the above ratio was $9-39 \%$ in cv. Bujna and $14-53 \%$ in Antocyjanowa.

We compared the further behaviour of these two branches. It was shown in all three cultivars that the prolongation of the apparent main axis was always more vigorous than the apparent lateral axis initiated at the same node (Figs. 8 and 9). 


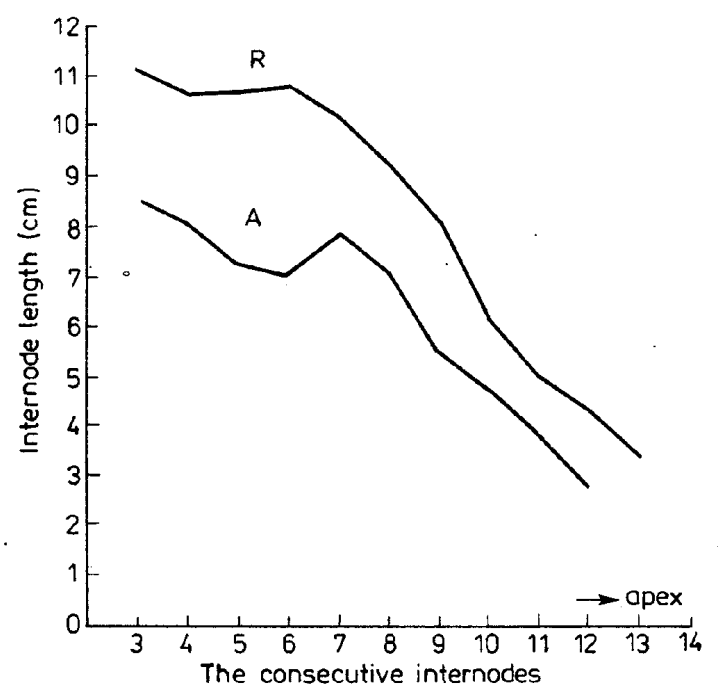

Fig. 5. The final length of the consecutive internodes of the apparent main axis of the two cultivars. A - Antocyjanowa, $\mathbf{R}$ - Rendidora

The true main axis is unbranched only during the beginning of the growing season. Later on, the angular shoots (true lateral branches) appear (Fig. 3). The individuals and populations differ markedly between each other concerning the number and vigour of these branches (compare Mulato-Brito et al., 1985). Their development proceeds according to the module: one-internode ending

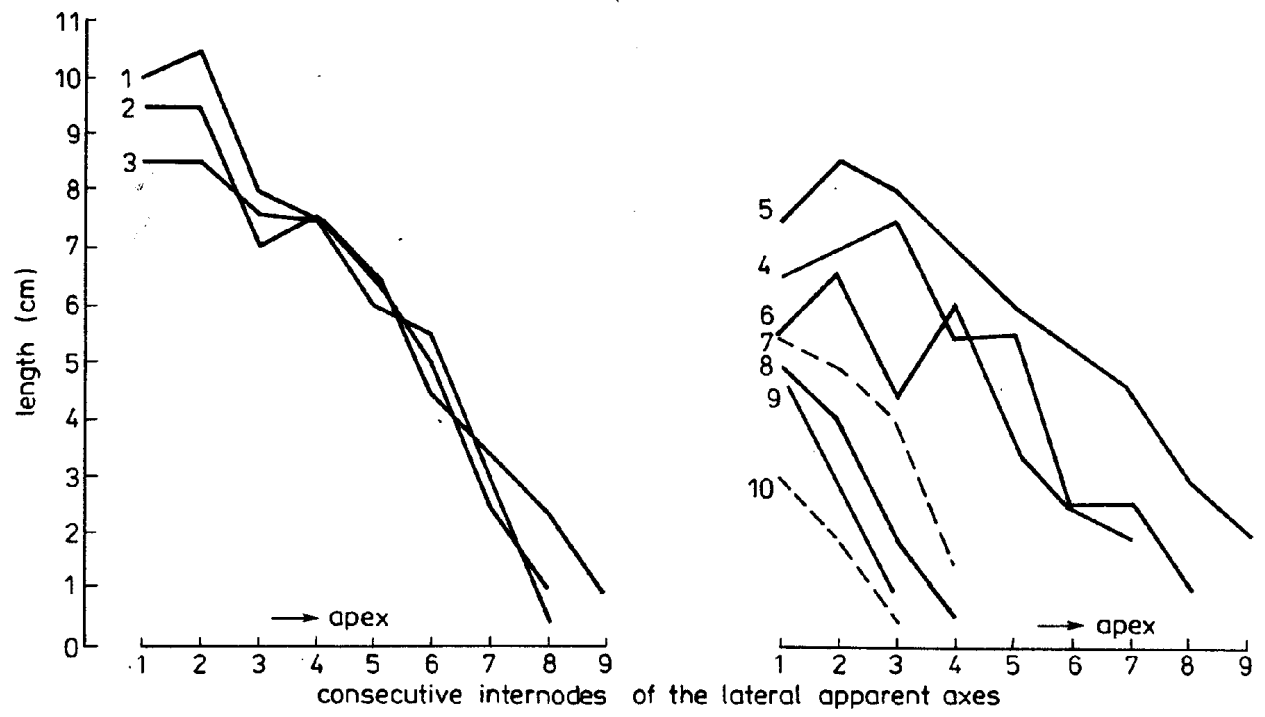

Fig. 6. Length of the consecutive internodes in the apparent lateral axes of tomatillo cv. Rendidora B1. Numbers 1-10 designate the consecutive apparent lateral axes. The axis 1 is the lowest. Other datails as on Figure 4. The data represent one plant. The others behaved similarly 


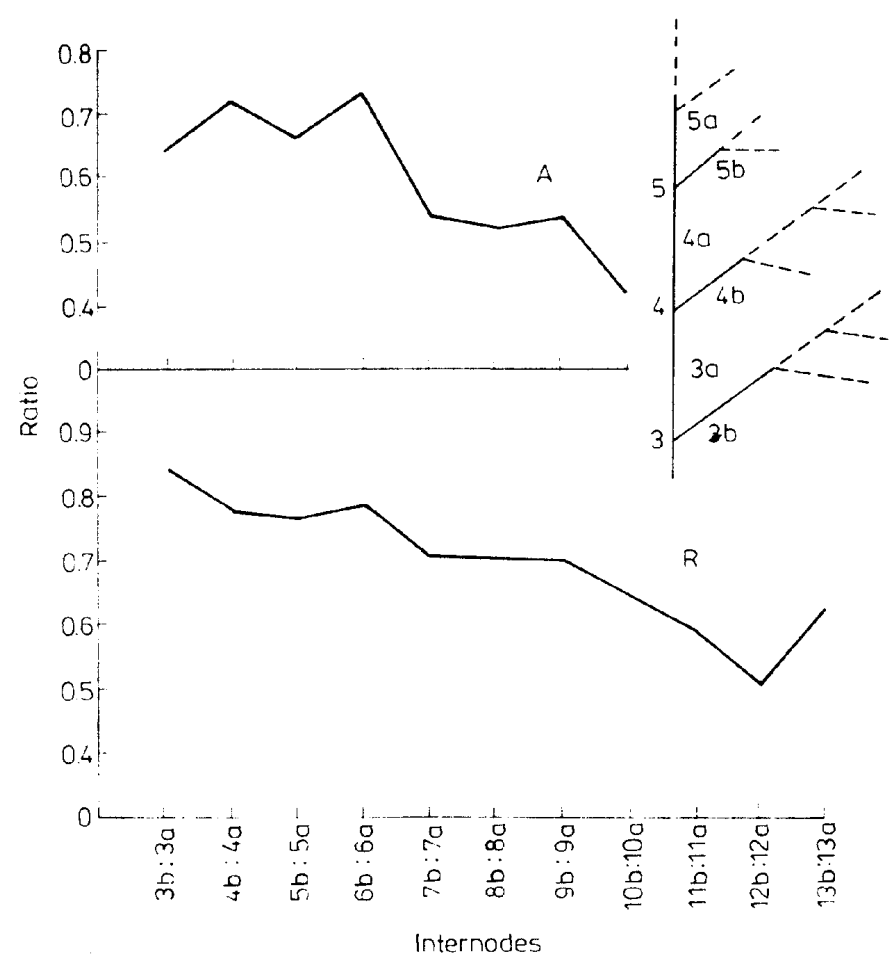

Fig. 7. Ratio of the length of two one-internode branches growing on the consecutive nodes of the apparent main axis of tomatillo cv. Kendidora B1 cultivated in the garden in 1986. The longer branch becomes a part of the main apparent axis, the shorter one initiates the apparent lateral axis

- see the scheme upper right. A - cv. Antocyjanowa, R - cv. Rendidora B1.

with a node having a flower bud, leaf and two lateral one-internode branches. These shoots, named by the authors, "shoots or branches on the trunk", are frequently damaged during cultivation etc.

When the vegetation period progresses, the leaves become increasingly smaller (Fig. 10), which may be considered a symptom of senescence. The leaves on the lateral axes are always smaller than those on the main axis (Fig. 10). The coefficient of variability fluctuated between $3-36 \%$.

The dynamics of leaf growth is shown in Figure 11. Leaf growth lasted for about 25 days from the moment the leaves became measurable, i.e. when they were $1-2 \mathrm{~cm}$ long. The leaves on the apparent main axis were growing more vigorously than those on the apparent lateral ones.

Observations were conducted on methods of tying. Tying to sticks, as was practiced in 1986, seems unsatisfactory for prostated forms of tomatillo which predominated in the populations investigated. Their stems are too delicate and often break when the fruits become large. Tying to plastic strings extended 

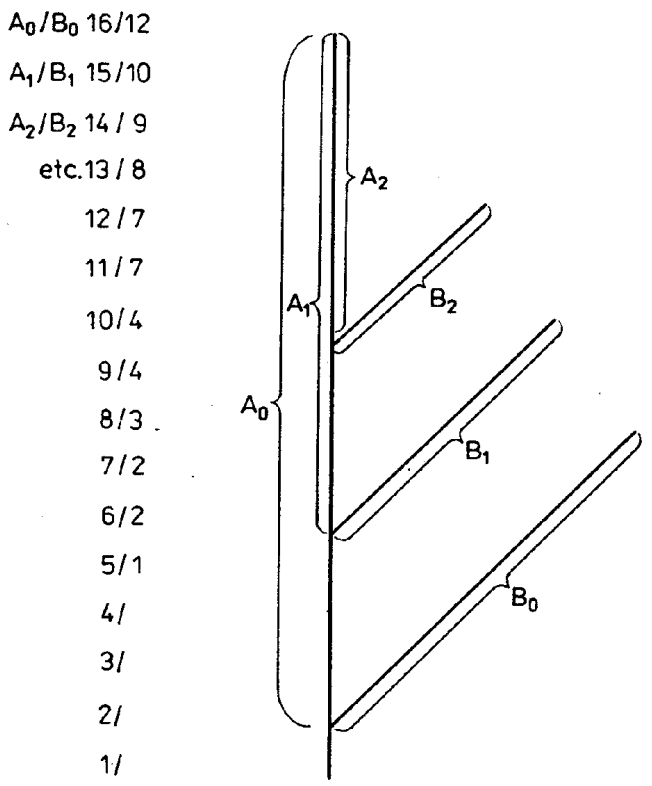

Fig. 8. Number of internodes in the prolongation of the apparent main axis (A) and in the apparent lateral axis (B) initiated from the same consecutive node (see the scheme)

between the sticks placed $2 \mathrm{~m}$ apart seems better. Prevention should be made, however, to avoid gliding of the vertical strings over the horizontal string. The plants were not hilled up and it seems that this operation is unnecessary.

Observations on the resistance of tomatillo plants to late blight made in the field showed no infection in spite of the fact that tomato plants growing in the adjacent plots were heavily infected.

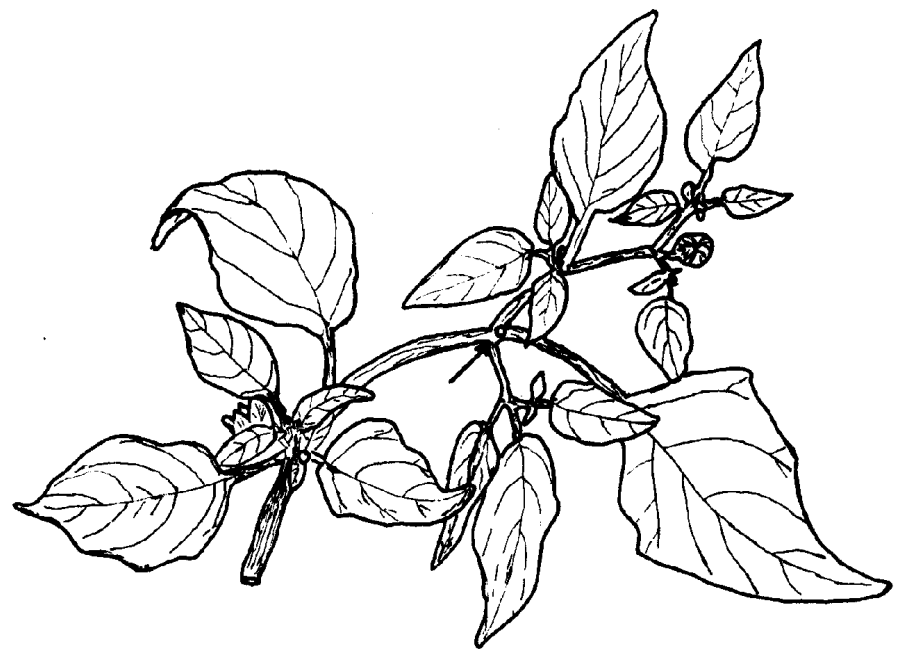

Fig. 9. In each node (for instance this marked with an arrow) one branch grows stronger than the other. The flower in the node marked with an arrow was abscised like it frequently occurs 


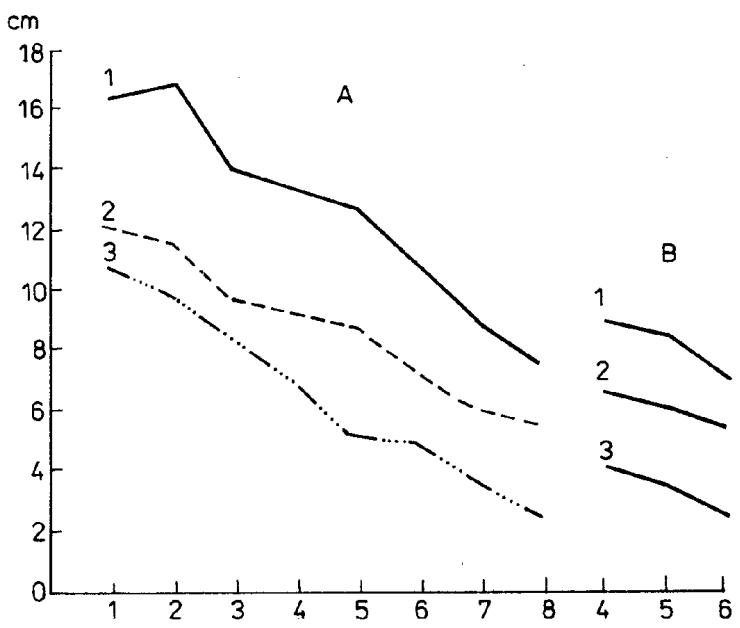

Fig. 10. Size of the leaves growing on the consecutive nodes of the main axis (A) and on the lateral apparent branch (B). 1 - leaf length, 2 - the width of the leaf, 3 - the length of the petiole. Averages for 4 plants of $\mathrm{cv}$. Rendidora B1 grown in a garden in 1987

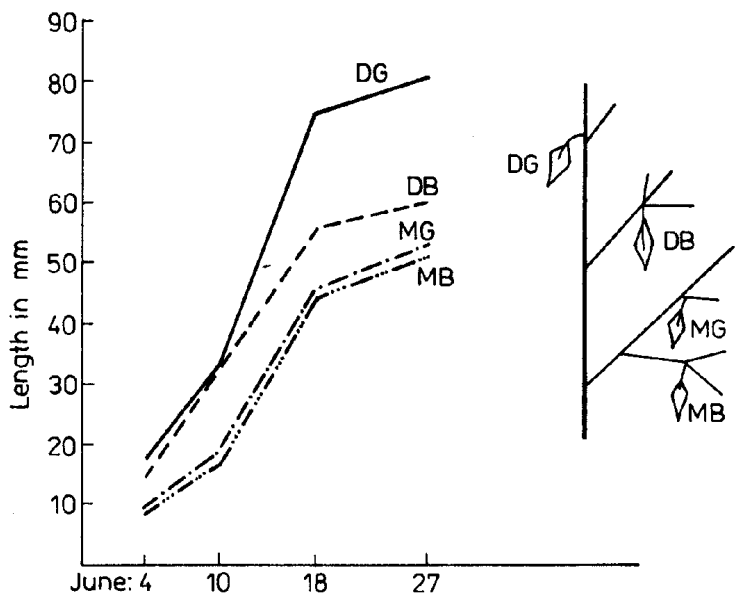

Fig. 11. Dynamics of leaf growth. Four leaves were measured on each plant - see scheme. Averages from 10 plants of cv. Rendidora B1 grown in the garden in 1987. DG - apparent main axis, DB - apparent lateral axis of the 1st order, first node, MG - as DB but second node, MB - apparent lateral axis of the 2nd order

Laboratory inoculation tests with leaves and fruits of tomatillo (Table 1) showed complete lack of late blight symptoms whereas the leaves and fruits of a susceptible tomato cultivar Riposta (Horodecka unpubl.) were heavily infected and those of partly resistant tomato cv. New Yorker (Robinson et al., 1968) were slightly infected (Table 1). The commonly accepted "models" of 
tomato resistance to late blight - the wild type tomatoes were also used: Virginia 700 (Galle gly, 1960), Ottawa 30 and Geneva T5 (D o rozh k in et al., 1982) and PI 224675 (Turkensteen, 1973). In this test their leaves were infected but the fruits, in general, healthy or slightly infected.

Virus diseases occurred frequently on tomatillo plants. This problem will be discussed later in a separate paper. Besides of that, the fruits are susceptible to grey mold. Insects were rarely found on this plant but some accarina were encountered and may have done some damage.

\section{DISCUSSION}

Tomatillo grows in Poland similarly like in Mexico but often the plants are more vigorous in Poland. This corresponds with the observation made in the USSR that tomatillo plants cultivated in the North are more vigorous than those in the South (Medvedev, 1958). The growth is connected with spacing. The spacing, $50 \times 100 \mathrm{~cm}$, seemed sufficient in our conditions for Rendidora plants. Garzon Tiznado and Garay Alvarez (1986) have found that spacing $50 \times 100 \mathrm{~cm}$ is one of the best in Mexico. The same spacing was used by Cartujano et al. (1985a, b) for Rendidora plants in Mexico. Some forms of Bujna plants perhaps will need more space in Poland.

The extention of the growth cycle of tomatillo in Poland is much longer than in Mexico (14 weeks in Mexico, State Morelos versus 20-23 weeks in Poland). Nevertheless, even most of the latest types of cv. Bujna terminated their growth and cropping toward the end of September.

In Mexico, the plants are often raised from transplants. In Poland, this is also necessary, at least for the late cultivars, since the vegetation period is short and the average temperatures relatively low in comparision to those in Mexico. However, trials may be performed to grow early cultivars from direct sowing. The seeds of tomatillo fruit left on the ground overwinter well and germinate in late April or in the beginning of May. Sometimes their earlier fruits ripen. In a climate warmer than that of Poland, this plant may become a weed, as is already the case in Spain (Cuartero et al., 1983).

Different local cultivars of tomatillo used in this experiment showed similar main characteristics of vegetative growth like the Rendidora plants in Mexico, described by Cartujano-Escobar et al. (1985 a, b) and Mulato-Brito et al. (1985). The plants of all local cultivars showed, for instance, unequal growth of the two branches from each node (Fig. 8) (exception in all cultivars are the branches on the first three nodes above the juvenile part).

The diminishing length of leaves and internodes which accompanies the progressing age of a plant may be considered a symptom of advancing senescence. This phenomenon may be explained as follows: the amount of nutrients available for each part of a plant decreases with the age of the plant, 
as is suggested by its decreasing Unit Leaf Rate (Cartujan o et al., 1987). The reason for this phenomenon may be an increasing participation in the plant body, of parts which are mainly consumers of assimilates (generative organs, stems etc.) (see Żelawski and Sztence1, 1981; Cartujano-Escobar et al. 1987). As a result of a scarcer and scarcer supply of assimilates to the developing leaves and internodes, they become smaller and smaller. This, in turn, may cause further limitation of the pool of assimilates available for growth.

The complete resistance of tomatillo to late blight was observed in field conditions in Reguly during several years, in spite of the fact that in some of them heavy infection of tomatoes and potatoes was noted.

Laboratory tests with tomatillo leaves and fruits conducted in 1988 also showed the resistance of tomatillo to this disease. The lack of symptoms of late blight infection in artificial conditions may indicate that tomatillo is wholly resistant to this disease or only to tomato strains of Phytophthora infestans. In order to receive a complete information on the resistance of tomatillo to this disease more tests, in different parts of the vegetative season will be made since the pathogenicity of the fungus probably changes during the vegetative season (Sujk owski, 1986) and the resistance of a plant may also depend on its stage of development (Berg, 1926; Mills, 1940; Gallegly, 1960; Dowley et al., 1981).

\section{Acknowledgments}

The authors are indebted to Miss Anna Gromek for her very good technical assistance. We are thankful to Abbe Simpkins for reading a part of the manuscript.

\section{REFERENCES}

Borkowski J., 1984. Pomidor skórzasty - nowe warzywo. Owoce, Warzywa, Kwiaty, 8: 5-6. Berg A., 1926. Tomato late blight and its relation to late blight of potatoes. W. Va. Agr. Exp. Sta. Bul. 205.

Cartujano-Escobar F., Jankiewicz L. S., Fernandez-Orduña V. M., Mulato-Brito J., 1985a. The development of husk tomato plant (Physalis ixocarpa Brot.) I. Aerial vegetative parts. Acta Soc. Bot. Pol. 54: 327-338.

Cartujano-Escobar F., Jankiewicz L. S., Fernandez-Orduña V. M., Mulato-Brito J., 1985b. The development of husk tomato plant (Physalis ixocarpa Brot.). II. Reproductive parts. Acta Soc. Bot. Pol. 54: 339-349.

Cartujano-Escobar F., Jankiewicz L. S., Fernandez-Orduña V. M., Mulato-Brito J., 1987. The development of husk tomato plant (Physalis ixocarpa Brot.). III. Growth analysis. Acta Soc. Bot. Pol. 56: 421-436.

Cuartero J., Costa J., Palomares G., Nuez F., 1983. Comportamiento de Physalis en condiciones de cultivo del sureste español. Sociedad Española de Ciencias Horticolas. Primer Congreso Nacional, Almeria, Spain, 1: 161-164.

Dorozhkin N. A., Neofitova V. K., Belskaya S. I., Bondar L. V., Chekalskaya N. I., 
Nitevskaya V. I., Nalobova V. L., Pomiksenova V. D., 1982. Metody povishenia ustoichivosti selskokhozyaistvennykh kultur $\mathrm{k}$ bolezniam. Nauka i Technika, Minsk, SSSR.

Dowley L. J., Routley D. G., Peirce L. C., 1981. Effect of carbohydrate content and daylength on resistance to late blight on tomatoes. Ir. J. Agric. Res. 20: 211-215.

Gallegly M. E., 1960. Resistance to the late blight fungus in tomato. Proc. Plant Sci. Seminar, Campbell Soup Co. pp. 113-135.

Garzon-Tiznado J. A., Garay-Alvarez R., 1986. Influencia de la densidad de población sobre el rendimiento y calidad de fruto en el cultivar 'Rendidora' de tomate de cáscara (Physalis ixocarpa Brot.). Proc. Trop. Reg. Amer. Soc. Hort. Sci. 23: 268-270.

Horodecka E., 1989. Laboratory methods of evaluating tomato resistance to late blight (Phytophthora infestans (Mont.) de Bary). Acta Agrobot. 42: 133-152.

Klinac N. J., Wood F. H., 1986. Cape gooseberry (Physalis peruviana). Orchardist of New Zealand, 59 (3): 103.

Medvedev P. F., 1958. Fizalis - Physalis L. [In:] Flora of cultivated plants. Vol. 20. Vegetable plants. Family Solanaceae. Brezhnev D. D. (ed.). State Agricultural Publishing Office, Moscow, pp. 488-501 (in Russian).

Mills W. R., 1940. Phytophthora infestans on tomato. Phytopathology, 30: 830-839.

Mula to-Brito J., Jankiewicz L. S., Fernandez-Orduña V. M., Cartujano-Escobar F., Serrano Covarrubias L. M., 1985. Growth, fructification and plastochron index of different branches in the crown of the husk tomato (Physalis ixocarpa Brot.). Acta Soc. Bot. Pol. 54: 195-206.

Robinson R. W.. Shannon S.. Schroeder W. T.. Provvident R.. Robinson W. B.. 1968. New Yorker - an early tomato variety with a bonus. Farm. Res. 32: 6-7.

Rojas-Rabiela T. (ed.) 1983. La agricultura chinampera. Compilación Histórica. Universidad Autónoma Chapingo, Dicrección de Difusión Cultural, Chapingo, Méx., México.

Saray-Meza C. R., 1977. Tomate de cáscara, algunos aspectos sobre su fisiología en investigación. Campo Agr. Exp. Zacatepec. CIAMEC-INIA-SARH.

Saray-Meza C. R., Loy a R. J., 1978. El cultivo de tomate de cáscara en el Estado de Morelos. Campo (México), 54 (1040): 30-38.

Saray-Meza C. R., Palacios A. A., Villanueva E., 1978. Rendidora, nueva variedad de tomate de cáscara. Campo (México), 54 (1041): 17-21.

Sujkowski L. S., 1968. Seasonal variation in pathogenicity of Phytophthora infestans. J. Phytopathology, 117, 160-172.

Turkensteen L. J., 1973. Partial resistance of tomatoes against Phyiophthora infestans, the late blight fungus. Ph. D. Thesis, Wageningen.

Walter H., Leith H., 1960. Klimadiagram Weltatlas. G. Fisher. Iena.

Wilson J. R. E., Gallegly M. E., 1955. The interrelationship of potato and tomato races of Phytophthora infestans. Phytopathology 45: 473-476.

Żelawski W., Sztencel I., 1981. Relative growth rate and its ontogenetic drift in growth analysis of plants. Acta Physiol. Plant. 3: 85-94.

\section{Rozwój i uprawa miechunki pomidorowej (Physalis ixocarpa Brot.)}

w warunkach klimatycznych Polski.

I. Badane odmiany lokalne, wzrost nadziemnych części wegetatywnych, prawdopodobna odporność na zarazę ziemniaczaną

\section{Streszczenie}

Miechunka pomidorowa (Physalis ixocarpa Brot.) rośnie w Polsce podobnie jak w Meksyku, jednak jej cykl rozwojowy jest znacznie dłuższy i trwa około 6 miesięcy. Sieje się ją w początkach kwietnia w szklarni ogrzewanej i potem ewentualnie przenosi do ogrzewanych tuneli. Do gruntu 
wysadza się ją około 20 maja, gdy minie niebezpieczeństwo przymrozków. Badano trzy odmiany lokalne miechunki meksykańskiego pochodzenia i podano ich krótki opis. Wzrost części wegetatywnych wymienionych odmian byl podobny jak $\mathbf{u}$ odmiany Rendidora opisanej poprzednio w Meksyku. Liście i międzywęźla miechunki stają się coraz mniejsze $\mathrm{z}$ wiekiem. Liście i owoce miechunki nie są atakowane przez zarazę ziemniaczaną w polu, a ich inokulacja zoosporami ras pomidorowych tej choroby nie spowodowala zakażenia. 